\title{
Legal Aspects of Labor Migration and Trafficking in Human Beings
}

\author{
Lasha Kukhianidze, PhD Student \\ Grigol Robakidze University, Tbilisi, Georgia
}

doi: 10.19044/esj.2016.v12n35p483 URL:http://dx.doi.org/10.19044/esj.2016.v12n35p483

\begin{abstract}
The paper deals with the legal aspects of the problems of labor migration and human trafficking, its causes and factors, the trafficking scale. When considering economic causes we refer to the demand for low-cost labor, as a characteristic factor of globalization, which in turn, greatly effects the international labor migration and is one of the root causes of human trafficking. In the analysis of the social causes the focus is mainly made on the low-pay employment or lack of working conditions.
\end{abstract}

Keywords: Labor migration, trafficking, violence.

\section{Introduction}

Labor migration is an employment in a foreign country for a certain period. Globalization has triggered the largest floods of migrant workers. The processes that have developed worldwide show that by the end of 2016 the number of persons legally employed abroad will reach 150 million. The amount of money sent by migrant workers to the countries of their citizenship will exceed 500 billion US dollars.

In the last decades, the number of migrant workers has especially increased. The twentieth century has witnessed the unprecedented mobility of population. The number of people living outside their homeland exceeded 180 million or more than 3 percent of the world's population in 2006, from which 86 million were migrant workers. In 2007 the number of international migrants exceeded 200 million. Now there are about 300 million international migrants worldwide, where 84 percent are the citizens of developing countries of Asia, the Pacific, Africa, Latin America and the Caribbean as well as the Commonwealth of Independent States and SouthEast Europe. Compared with other continents the level of migration from Europe is low. 
Labor migration is linked to the factors such as social protection ${ }^{78}$ and economic development dynamics, labor standards and employment policy, the demographic situation, trafficking and labor exploitation.

Labor migration between the sending and host countries should be based on the fair and legal principles, in order to promote decent employment, reduction of unemployment rate and overcoming the qualified workforce deficit. During the last quarter-century the rate of labor migration has been extremely high.

On October 13, 2010 under the decree N 314 of the Cabinet of Ministers of Georgia the Migration State Commission was established, on the basis of drafted document of which the Cabinet of Ministers of Georgia adopted the Decree N59 "On the Approval of Migration Strategy" on the March 15, 2013. In accordance with this Decree the Government in 20132015 carried out the migration strategy.

The issue drew attention of the country's highest legislative body as well. The Parliament of Georgia has ratified the provisions of all fifteen paragraphs of the labor migration related Article 19 of Part II of the European Social Charter. It also has ratified the UN International Labor Organization Convention No. 88 "Employment Service Organization" and Convention No. 181 "Private Employment Agencies", but the country's highest legislative body has not still ratified the ILO's core conventions regulating the labor migration. The country adopted the Labor Migration Law as well as the Law of Georgia "On the Legal Status of Foreigners and Stateless Persons", which provide that the employment of foreigners in Georgia is regulated by the legislation.

The UN International Labor Organization has adopted a number of documents related to the labor migration and migrant workers, such as Migration for Employment Convention No. 97 of 1949, Migrant Workers Convention No. 143 of 1975, and the additional recommendations to the latter were adopted in the same year. These are the conventions which have not been ratified by the Parliament of Georgia.

The UN International Labor Organization's 1998 Declaration On Fundamental Principles and Rights at Work highlights that the dignity and rights of migrant workers should be firmly protected with others. The same is served by the UN International Convention On the Rights of All Migrant Workers and Members of Their Families adopted as early as on December 18, 1990. The day of eighteenth of December is appointed by the UN as the International Migrants Day.

${ }^{78}$ International Labor Office, ILO Action against Trafficking In Human Beings, ILO Publication. 2008. 
The international migration qualification stipulates the following kinds and forms of the migration: permanent, long-term, temporary, transit, involuntary, voluntary, legal, illegal, illicit, labor, educational, medical. Labor migration is often explained as a rational choice, when labor migrants know the movement costs and the potential profit from it. It is considered the most affordable means of remuneration.

Movement of people across international borders for trade, protection and work is the same ancient phenomenon as the existence of the borders. At present, many humans move between the continents, partly as tourists, partly in the form of the workforce who migrate against the wishes leaving unfavorable conditions in their own countries. The reasons that trigger many people to apply for labor migration are enormous in number. Such reasons affect the integrity at the individual, family and socio-economic levels. Mostly migrant workers are moving seeking better working conditions and employment. As far as labor migration and displacement issues are related to the border crossing it is the international phenomenon. Thus it is the reason of many of the conventions and agreements and the subject to the international regulation. The labor migration is one of the important segments of the labor relations regulation and employment policy with the overwhelming threats. Therefore, great efforts are directed towards the protection of the rights of migrant workers. However, the risks and losses still accompany the labor migration process.

The process of movement for labor migration and employment is linked to the factors such as the socio-economic situation of the country of citizenship, the efficiency of job creation and employment policies, demographic aspects, anti-trafficking issues and other.

The global illegal labor migration is growing; the number of illegal labor migrants is increasing, but in recent years the rights of illegal labor migrants expands at the international and regional levels along with the growth of their number. Migrant workers are admitted by foreign countries to implement a certain economic activity only for a certain period, which can be extended or renewed after the expiry of this period.

\section{Legal aspects of the labor migration regulation in Georgia}

Georgia has ratified the European Social Charter, also other conventions, which are to some extent related to labor migration: ILO Private Employment Agencies Convention (No. 181), ILO Employment Service Organization Convention (No. 88), the Discrimination (Employment and Occupation) Convention (ILO Convention No. 111), also the conventions that regulate trafficking issues.

In the context of bilateral relations the cooperation in labor migration regulations between Georgia and the EU is very important. Under the Decree 
N59 of March 2013 the Government of Georgia adopted the migration strategy for 2013-2015, which covered the area of labor migration. The government of Georgia has set a goal to develop a legal framework to secure the positive effect of the legal, temporary and labor migration, as well as protection of migrant workers' rights and security.

The Law of Georgia “On the Procedure of Exit of Citizens of Georgia from Georgia and Entrance to Georgia” does not directly regulate the legal aspects of labor migration; it generally regulates the emigration permit issuance, refusal of issue or revocation of the permit, emigration of minors and other issues.

Under the law of Georgia "On the Legal Status of Foreigners and Stateless Persons”, the foreigner's labor activity shall be defined by the Georgian legislation. However, so far, there is no such normative act. The law provides the general rules and procedures which are applied in labor migration issues. The law declares the universally recognized principles and values. The entrance to, presence in and exit from Georgia by a foreigner is based on the principle of family unity. Discrimination is prohibited. The alien has the same rights and freedoms as those of citizens and undertakes the same obligations as a citizen of Georgia.

\section{Aspects of illegal migration from Georgia}

In Georgia there is no accurate data of the illegal migration because of the nature of this phenomenon. The International Organization for Migration has conducted the survey to make its approximate picture that creates prerequisites for development of the mechanisms to combat illegal migration.

The majority of illegal migrants and victims of human trafficking avoid to make public their troubles. There are many reasons for this, specifically; they care for the family traditions. This creates good conditions for the people, for whom traditional values are not common and who illicitly enrich themselves due to the public's attitude toward illegal immigration and trafficking in human beings. IOM has managed to interview 270 illegal repatriated migrants, of which 264 persons are citizens of Georgia. Some respondents, 72 percent had traveled abroad in 1996-1999, 17 percent - in 2000-2001. A large part of illegal migrants, 69 percent, are women, 86 percent of them became victims of the human trafficking, while in men the figure is 13 percent.

The age of victims of human trafficking is mainly 21 to 30 years and about 50 percent is single and 25 percent - divorced. Almost without exception, the participants in illegal migration had left Georgia seeking job. 90 percent of respondents admitted this as the main motive for illegal migration. 13 percent of victims of trafficking noted that the extreme social 
and economic problems had forced them to temporarily leave for a foreign country in search of bread and butter.

Trafficking in respect of illegal migrants means cheating, intimidation and brutality and is used for the forced adaptation of migrants to local conditions. The majority of victims of human trafficking were not able to receive their salary in full amount.

Almost all victims of trafficking, 92 percent, who have returned to Georgia, stated that they had had big problems to return to a normal rhythm of life. 62 percent of the illegal migrants stated about the same, 38 percent had had no problems in this aspect. Some of them stated that the money accrued abroad, helped them to improve their living conditions in the homeland.

\section{General characteristics of trafficking in human beings}

The gravity of human trafficking offense, infringement ${ }^{79}$ of honor and dignity, physical or mental health disorder makes the trade in people (human trafficking) a gross violation of fundamental human rights and freedoms: its threats human physical and mental health, as the trafficking characteristics in most cases are expressed in the physical and psychological violence such as deprivation of liberty, coercion, slavery etc.

The next factor is the scale of this crime. According to the US annual reports, every year about 800000 people become victims of trade in people (human trafficking), 80 percent of which are women ${ }^{80}$ and girls, of which 50 percent are youngsters. Also, an important factor is the profits gained from this crime. After arms and drug trafficking, the illegal business of the trade (trafficking) in human beings brings to the criminal world bosses about $\$ 7$ billion in revenues every year.

Trafficking causes can be grouped according to different criteria, such as: economic, social, political and technological.

Out of economic reasons one of the main is the demand for cheap workforce. The globalization feature is the market integration beyond the borders. In spite of the laws adopted to regulate the labor force migration in order to preserve the principle of the respect for the state sovereignty, the globalization, however, has had a significant effect on international labor migration. Labor migration is caused by many factors, including socioeconomic and political crisis. One of the contributing factors is the employers' demand for cheap manpower in the destination (host) countries, occupying the jobs undesirable for local workers or less remuneration paid to the illegal workers or foreign labor.

\footnotetext{
${ }^{79}$ International Agreement for the Suppression of the White Slave Traffic, League of Nations Treaty Series, Paris, 1904;

${ }^{80}$ (2011). Trafficking women's human rights., University of Minnesota Press
} 
Given the above, it is necessary to draw the attention of the governments to the criminalization of trafficking, the availability of appropriate legislative framework and the scale of steps to be taken by the government for the implementation of the legislation.

The first definition of trade ${ }^{81}$ in people (trafficking in human beings) was provided in the United Nations Convention against Transnational Organized Crime ${ }^{82}$, adopted by General Assembly resolution 55/25 of 15 November 2000, and the Protocols thereto to prevent, suppress and punish trafficking in persons, especially women and children. However, in the last century, the world community tried a variety of ways to create a legal framework for human trafficking prohibition that is evidenced by a number of international legal acts which concern slavery, ban of forced labor and the human trafficking.

After the establishment of the League of Nations, the 1921 International Convention for the Suppression of the Traffic in Women and Children adopted in the frames of the League of Nations had further expanded the list of countries across Europe, but the United States had not joined this Convention.

Next international document that directly related to the prohibition of slavery was adopted in 1926. The Convention had been preceded by a certain work, in particular, in 1924 the League of Nations aiming prevention of the African slave trade, created an ad hoc commission, which had been entrusted to make a report thereof. In 1926, the League of Nations adopted the Convention on slavery, which came into force in 1927.

In 1956, the United Nations adopted the Supplementary Convention on the Abolition of Slavery, the Slave Trade, and Institutions and Practices Similar to Slavery, in the Preamble of which there was stated that slavery, the slave trade and institutions and practices similar to slavery have not yet been eliminated in all parts of the world as laid down in the 1926 Convention. The provision is notable in the sense that the elements listed in it have been recognized in the laws of many countries, including Georgia, as the elements of trafficking in human beings. ${ }^{83}$

This convention is remarkable as it has declared debt bondage, forced marriage and some forms of child labor unlawful. According to the first Article of the Convention, "each of the States Parties to this Convention shall take all practicable and necessary legislative and other measures to bring

\footnotetext{
${ }^{81}$ Krieg S.H. Trafficking in Human Beings: The EU Approach between Border Control Law Enforcement and Human Rights, European Law Journal Review, vol. 15, Blackwell publishing. 2009.

${ }^{82}$ United Nations Convention against Transnational Organized Crime and the Protocols Thereto

${ }^{83}$ Note to Article 143' of the Criminal Code of Georgia
} 
about progressively and as soon as possible the complete abolition or abandonment of the following institutions and practices”.

Another important document is the International Criminal Court Statute, which was opened for signature on July 18, 1998 in Rome. Due to the fact that the ICC Statute was opened for signature as a result of the conference held in Rome, it is also called the Rome Statute. The Rome Statute determines the following issues assigned to the jurisdiction of the Court: the crime of genocide, crimes against humanity, war crimes and crime of aggression. Article 7 of the Rome Statute lists the crimes against humanity, including "enslavement", which is defined as the exercise of any or all of the powers attaching to the right of ownership over a person and includes the exercise of such power in the course of trafficking in persons, in particular women and children.

The modern definition of slavery ${ }^{84}$ means using a human as an item, which can be engaged in forced labor and sex industry, legal or illegal business activity, components of military conflicts.

Article 3 of the UN TIP Protocol to the Palermo Convention, is extremely important, since the elements provided by its definition provides are shared in the legislation of many countries: "Trafficking in persons" shall mean the recruitment, transportation, transfer, harboring or receipt of persons, by means of the threat or use of force or other forms of coercion, of abduction, of fraud, of deception, of the abuse of power or of a position of vulnerability or of the giving or receiving of payments or benefits to achieve the consent of a person having control over another person, for the purpose of exploitation. Exploitation shall include, at a minimum, the exploitation of the prostitution of others or other forms of sexual exploitation, forced labor or services, slavery or practices similar to slavery, servitude or the removal of organs.

In addition to the Palermo Convention and its protocols, in terms of combating human trafficking the struggle against trafficking of minors is very important as well. Trafficking in minors is gradually expanding and gaining such forms, as organized prostitution, pornography, sex tourism and other. Exploitation of a minor is expressed mainly in the following forms: commercial sexual exploitation, trafficking in organs (forced donation), engagement in criminal or other antisocial actions. Before adoption of special laws against trafficking in human beings the states shall apply the criminal law for prosecution and punishment in order to punish slavery, practices similar to slavery, forced labor or prostitution exploitation, unlawful restraint and other similar actions.

${ }^{84}$ Human Trafficking: the Facts (UNODC, 2009) 

follows:

We can generalize main kinds and forms of human trafficking as

1. Human trafficking for the purpose of labor exploitation, the victims of which are men, women and children, means the labor in the informal and shadow economy, household conditions as well as the use of forced labor of prisoners and military personnel.

2. Human trafficking for the purpose of sexual exploitation, the victims of which are mostly women and children, including: enforced prostitution, sex tourism, including the children's sex tourism, pornography.

3. Human trafficking for the purpose of forced beggary, the victims of which are children, people with disabilities and the elderly.

\section{Trafficking in the Georgian legislation}

In 2003 the Criminal Code of Georgian was added two Articles $143^{1}$ and $143^{2}$ which provide criminalization of trade (trafficking) in human beings.

In the crimes provided by Article $143^{1}$ of the Criminal Code of Georgia the object of legal protection is the human personal rights and freedoms recognized by the Constitution. In particular, the right to free movement throughout the country, inviolability of human freedom, the right to choose a place of residence and work, integrity of his dignity. An optional object of this crime is human life and health.

The objective aspect of this crime can be divided into several groups:

a) capture, purchase of human trafficking victims, other illegal transactions, winning over;

b) their recruitment - concealment, hiring;

c) their handover - transfer, transportation.

Objectively this crime may be committed mostly by an action. However, it is possible to commit this crime by an omission, for example, to hide such fact. The crime is over upon the commitment of any of the actions listed in the disposition and not necessarily upon the occurrence of any serious outcome. So it is a formal offense.

The subject of the crime of trafficking is a person who has attained the age of 14 years. Subjectively human trafficking is and e-liberate crime committed with the direct intent. The motive of the crime provided by this article may be envy, covetousness and other, but for the qualification of this crime the motive is not significant, it can be considered during the punishment.

In the crimes provided in Article $143^{2}$ the object of legal protection is the minor's personal rights and freedoms. In particular, the integrity of 
his/her personality, his right to grow up with his/her parents, honor and dignity, which is recognized in the Constitution of Georgia as well as in the international acts.

The Convention on the Rights of the Child recognizes the child's right to be protected from economic exploitation and from performing any work that could pose a threat to the child, or to interfere with the education of, or inflict harm to the child's health or physical, mental, moral, spiritual and social development. Optional object is the minor's life and health.

A victim of the crime is a minor, i.e. a person under the age of 18 .

Objectively this crime resembles a crime provided for in Article $143^{1}$, but with the difference that the trade in minors does not always require coercion, blackmail or deception, or other methods referred to in paragraph 1 of Article $143^{1}$. Recruitment, transfer or suppression of a minor can be performed by encouraging, admonishing, convincing a minor, because his/her psyche is not yet formed, and the influence on it causes sorrowful effect.

A perpetrator of the crime is a person of full capacity who has attained to the age of 14years. Subjectively the trafficking in minors is a directly intentional crime, the offender is aware that he or she carries out trade in a minor and wants it, at the same time, in a number of cases of recruitment, transportation, hiding or reception he or she should pursue a special purpose of exploitation. According to the definition of the term "exploitation", the purpose of exploitation is placing a human in the modern conditions of the human slavery that is defined in the Georgian legislation, as "depriving him/her of IDs, restricting the right of free movement, prohibiting contacts with the family, including correspondence and phone calls, cultural isolation, forcing into working under inhuman or degrading conditions or without any or with inadequate compensation”.

In the criminal theory in respect of a crime of human trafficking, they separate restriction on the right to free movement and restriction of freedom. In case of illegal restriction of freedom, a victim is deprived of the right to move freely throughout the country, does not have the physical ability to move across the area defined by the offender, he or she is closed in the apartment or elsewhere. In case of restriction of the right to free movement, the victim with the consent of the offender is given the opportunity to go beyond the limited area and go on the streets, but is not able to move around there and shrinks from meeting with the police. In addition, he or she has no money, which would give the opportunity to travel, and he or she does not speak a foreign language, and so forth.

Using deception in case of trafficking deprives the victims of the opportunity to realize that he or she is exploited; he or she thinks that he or 
she will get a lump compensation and therefore a restriction of the right to free movement takes place by this method.

\section{Conclusion}

Trafficking is a violation of fundamental human rights and together with other rights one of the main rights - the right to freedom from slavery, is violated. Trafficking poses a threat to Georgia due to the country's geopolitical location and the difficult economic situation, which is why Georgia is considered as a state of the origin and transit of victims of trafficking. The situation is exacerbated by the fact that a large part of the population of our country has left the homeland looking for a job abroad, and the majority of them stay in foreign countries illegally.

In recent years Georgia has made significant steps against trafficking in human beings, has ratified the relevant UN Conventions, protocols, regulations, shared human trafficking laws in Europe.

However, there is still much to be done to counter the threat of trafficking for the Georgian population.

1. The availability of appropriate shelter shall be guaranteed for the persons; in case of the victims of trafficking in minors, it is necessary to strengthen the relevant departments of social services and their active involvement in the protection of minors and the implementation of the assistance and aid measures. The social service shall play the leading role and implement the coordinated and reasonable actions.

\section{Crimes committed as trafficking in human beings, unit ${ }^{85}$}

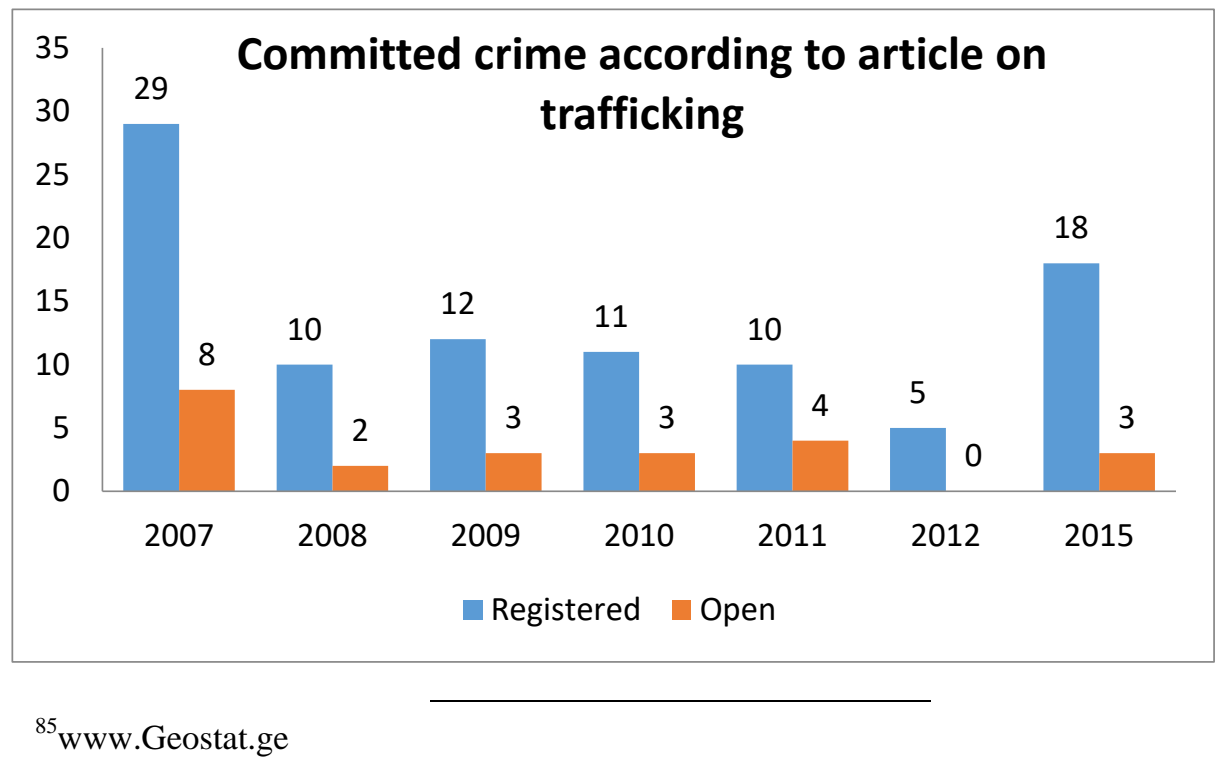




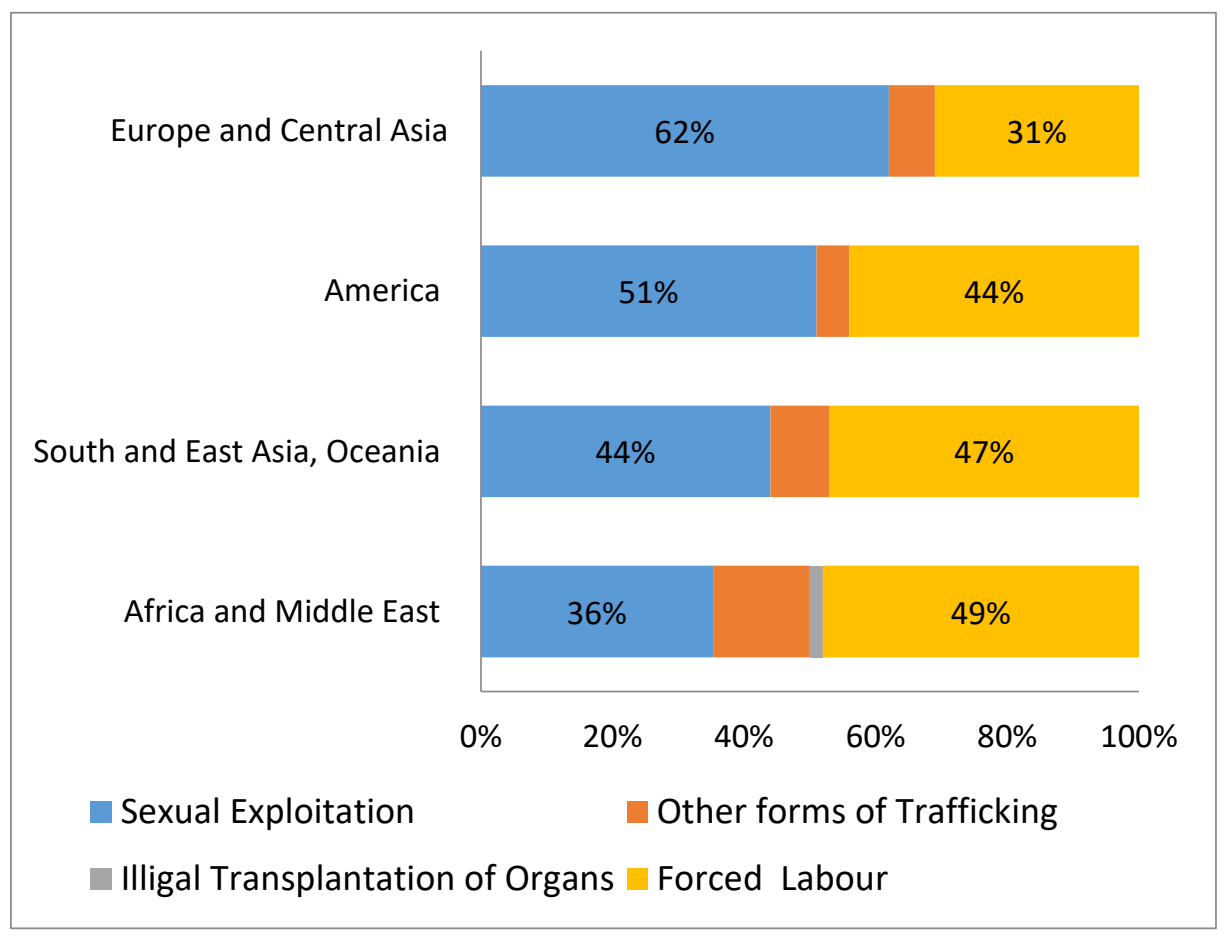

\section{References:}

1. Cho,S-Y, Dreher, A \& Neumayer E. (2014). The determinants of anti trafficking policies - evidence from a new index. Scandinavian Journal of Economics 116 (2). P. 429-54.

2. Downes P. Zule-Lapimaa A. Ivanechchko L. Blumberg A. Not One Victim More: Human Trafficking in the Baltic States, Living for Tomorrow. 2008.

3. International Labor Office, ILO Action against Trafficking In Human Beings, ILO Publication. 2008.

4. Krieg S.H. Trafficking in Human Beings: The EU Approach between Border Control Law Enforcement and Human Rights, European Law Journal Review, vol. 15, Blackwell publishing.

5. Studies and the IFO Institute at Ludwig-Maximilian University. Powell, C. (1995).

6. Vulnerability in the marketplace: concepts, caveats, and possible Solutions. Journal of Macro marketing, 25 (2) (December), 202-14.

7. Zimmerman, Y. (2011). Christianity and human trafficking. Religion Compass 5, 567-578.

8. Obokata T. EU Council Framework Decision on Combating Trafficking inhuman Beings: A Critical Appraisal, Common Market Law Review, vol. 40 Number 3, Kluwer Law International. 2003 
9. Victims of Trafficking in Human beings o Who are the Subject of an Action to facilitate Illegal Immigration, Who Cooperate with the Competent Authorities 2004/EC, [2004] OJ L 261/19. Recommendations on the Framework Decision on Combating Trafficking in Human Beings COM (2000) 854 final/2, Bruxelles, September 14, 2001. 